\title{
„Pełne wzlotów i upadków” — o charakterze i zachowaniu DZIEWCZYNY w listach z prasy młodzieżowej
}

\author{
"Full of Ups and Downs" - \\ About the Character and Behaviour of a GIRL \\ in the Correspondence Excerpted from the Youth Press
}

Summary: The article presents a selected, broadly understood semantic category of the linguistic-cultural (auto)stereotype of A GIRL — 'her character and behaviour'. The research materials has been excerpted from both older and more contemporary letters published by the youth press. The text aims to illustrate the stereotype (and its potential alterations) over the span of thirty years. Auto-stereotypical descriptions recreated from the girls' letters have been enriched with the boys' comments (hetero-stereotypical approach). The excerpts, which constitute the reconstructed category, have been divided into three subgroups: 1) characteristics and behaviour socially perceived as positive, 2) characteristics and behaviour typical for adolescence, 3) characteristics and behaviour socially perceived as negative. The highest percentage of linguistic data regards adolescence related issues.

Key words: girl, stereotype, characteristics, behaviour, youth press

$\mathrm{Na}$ temat funkcjonującego w polszczyźnie obrazu płci pięknej wciąż pisze się wiele. Literatura przedmiotu zwykle traktuje o językowo-kulturowym „portrecie” osoby dorosłej". W kręgu zainteresowań badaczy mieści się rów-

${ }^{1}$ Dla rozważań istotnych w tym tekście ważne są studia, które dotyczą funkcjonowania wyobrażenia płci pięknej w języku (w tym w słownictwie, frazeologizmach i przysłowiach). Zob. E. Jędrzejko: Kobieta w przystowiach, aforyzmach i anegdotach polskich. Konotacje i stereotypy. „Język a Kultura”. T. 9: Płeć w języku i kulturze. Red. J. Anusiewicz, K. Handke. Wrocław 
nież rekonstrukcja obrazu młodej osobniczki², w tym jej wizerunku medialnego ${ }^{3}$.

Ogólnie rzecz biorąc, dziewczyna to 'młoda, raczej niezamężna, kobieta'4. To znaczenie podstawowe, zawierające cechy esencjonalne. Na pełniejsze rozumienie tego wyrazu, współtworzące stereotypowe ${ }^{5}$ wyobrażenie jego desygnatu wpływa cały szereg konotacji, które uwarunkowane są m.in. szeroko rozumianym dziedzictwem kulturowym języka oraz indywidualnymi doświadczeniami jego użytkowników. Przedmiotem analizy w artykule jest to, w jaki sposób dziewczyna postrzega i językowo charakteryzuje samą siebie - autostereotyp i jak to czynią chłopcy — w tym znaczeniu będę używać określenia „heterostereotyp". Rekonstruując językowo-kulturowy stereotyp DZIEWCZYNY ${ }^{6}$, należy — jak sądzę — uwzględnić następujące kategorie semantyczne (fasety):

— nazwa / sposoby określania”;

- wygląd ${ }^{8}$

- charakter i zachowanie;

1994, s. 159-172; R. Łobodzińska: Jaka jest kobieta $w$ języku polskim?. „Język a Kultura”. T. 9: Płeć w języku i kulturze..., s. 181-186; M. Peisert: „On” $i$ „,ona” we wspótczesnej polszczyźnie potocznej. „Język a Kultura”. T. 9: Płeć w języku i kulturze..., s. 97-108; A. Pajdzińska: Kobieta najlepszym przyjacielem człowieka (przyczynek do językowego obrazu świata). W: Studia z historii języka polskiego i stylistyki historycznej. Red. C. Ko syl. Lublin 2001, s. 151159; M. Karwatowska, J. Szpyra-Kozłowska: Lingwistyka ptci. Ona i on w języku polskim. Lublin 2005; Eaedem: Obraz kobiety w stownictwie, frazeologii i przystowiach. W: Encyklopedia gender. Pteć w kulturze. Red. M. Rudaś-Grodzka et al. Warszawa 2014, s. 426-427.

2 Zob. M. Bancerz: Dziewczęta widzq siebie inaczej. „Polonistyka” 2001, nr 8, s. 488 -493; M. Karwatowska, J. Szpyra-Kozłowska: Lingwistyka ptci..., s. 139-167.

${ }^{3}$ Zob. W. Kajtoch: Ciało medialne. „Zeszyty Prasoznawcze” 2004, nr 3/4, s. 59-86; M. Karwatow ska: ,, Gazetowa” dziewczyna. Wybrane elementy wizerunku nastolatki w czasopismach młodzieżowych. W: Kultura popularna w szkole. Pobłażliwe przyzwolenie czy autentyczny dialog. Red. B. Myrdzik, M. Latoch-Zielińska. Lublin 2006, s. 141-150; B. Pytlos: Portret nastolatki kreowany na lamach miesięcznika ,Dziewczyna” w latach 2005-2009 (rekonesans badawczy). W: Młody odbiorca w kręgu lektur pożytecznych i szkodliwych. Red. K. Heska-Kwaśniewicz przy współpr. S. Gajownik. Katowice 2012, s. 167-173.

${ }^{4}$ Uniwersalny słownik języka polskiego. T. 1. Red. S. Dubisz. Warszawa 2003, s. 769.

5 Termin ,stereotyp” rozumiem zgodnie z etnolingwistyką kognitywną jako koncept, uznając go za utrwalone w języku i kulturze opisujące, a zarazem wartościujące (pozytywnie, neutralnie lub negatywnie), antropocentryczne, symplifikujące, subiektywne (postrzegane z określonych perspektyw i punktów widzenia) wyobrażenie kogoś lub czegoś. Zob. J. Bartmiński: Stereotypy mieszkaja w języku. Studia etnolingwistyczne. Lublin 2007; Idem: Językowe podstawy obrazu świata. Lublin 2009.

${ }^{6}$ Kapitalikami zapisuję koncepty, a kursywą elementy je współtworzące (np. profile).

7 Zob. M. Wacławek: Dziewczyna we współczesnych wypowiedziach polskiej młodzieży. Przyczynek do badań językowego obrazu świata. W: Veda pre vzdelanie - vzdelanie pre vedu. Minoritné kultúry, kultúra minorit. Red. A. Janiec-Nitrai, P. Šenkár. Nitra 2010, s. 89-98.

${ }^{8}$ Zob. M. Wacławek: Kategoria wygladu w językowo-kulturowym (auto)stereotypie dziewczyny. W: „Z Teorii i Praktyki Dydaktycznej Języka Polskiego”. T. 25. Red. D. Krzyżyk. Katowice 2016, s. 139-154. 
— zainteresowania';

- profile (warianty), np. uczennicy ${ }^{10}$ i partnerki ${ }^{11}$.

Niniejszy tekst dotyczy wybranej kategorii - charakteru i zachowania. Faseta ta rozumiana jest bardzo szeroko: obejmuje konstrukcje językowe, które mają na celu opisanie własności psychicznych, orzekających coś o osobie, informujących o jej zachowaniu, w tym jego powtarzalności, i zawierających odpowiednie wartościowanie ${ }^{12}$.

Podstawę materiałową artykułu tworzą dane językowe wyekscerpowane $\mathrm{z}$ listów publikowanych $\mathrm{w}$ prasie młodzieżowej z lat 1979-1980, na przykładzie „Filipinki” (F) oraz bardziej współczesnej, z lat 2009-2011, mającej polskich wydawców („Viktor Gimnazjalista” — VG; „Cogito” — C) — umownie nazwanej POL, a także zagranicznych („Bravo”- B; ,Twist” — T; ,Popcorn" - P) — określonej jako $\mathrm{POP}^{13}$. Artykuł służy wskazaniu na przestrzeni trzydziestu lat ciągłości i ewentualnych modyfikacji w analizowanej kategorii stereotypowego obrazu DZIEwCZYNY. Jestem świadoma pożytków oraz słabszych stron związanych z badaniem listowego obrazu „medialnego"14.

Eksploracja tekstów wyłoniła łącznie 378 konkretyzacji (ekscerptów) wpisujących się w fasetę 'charakter i zachowanie' DZIEWCZYNY, w zdecydowanej większości - $334^{15}$ - pochodzących z listów autorstwa młodych kobiet. Teksty

${ }^{9}$ Zob. M. Wacławek: Co ceni ,„dziewczyna”? Rozważania nad językowym obrazem świata wartości młodzieży licealnej. „Slavica XXXIX-XL. Annales Instituti Slavici Universitatis Debreceniensis". Red. K. Agyagási, Z. Hajnády, L.K. Nagy. Debreczyn 2010-2011, s. 83-95; Eadem: Świat wartości dziewczyny w opinii uczniów klas gimnazjalnych. W: „Z Teorii i Praktyki Dydaktycznej Języka Polskiego". Red. H. Synowiec. T. 22. Katowice 2013, s. 131-148; Eadem: Zainteresowania dziewczyny dawniej $i$ dziś - na podstawie wypowiedzi młodzieży. W: Językowe, literackie i kulturowe ścieżki edukacji polonistycznej (tradycja i wspótczesność). Red. D. Krzyżyk, B. Niesporek-Szamburska. Katowice 2014, s. 401-415.

10 Zob. M. Wacławek: Oprofilu uczennicywstereotypie dziewczyny. W: Wkrajobraz literacko-kulturowy i językowy wpisane... Ksiega jubileuszowa dedykowana Profesor Bernadecie Niesporek-Szamburskiej w czterdziestolecie pracy naukowej i dydaktycznej. Red. A. Guzy, D. Krzyżyk, M. Ochwat, M. Wójcik-Dudek. Katowice 2018, s. 393-406.

${ }_{11}$ M. Wacławek: Przemiany profilu partnerki w stereotypie dziewczyny. „Postscriptum Polonistyczne" 2017, nr 2, s. 209-222.

12 Zob. K. Kleszczowa: Konstrukcje opisujące cechy osobowości. „Polonica” 1986, t. XII, s. 9-20. Przyjęcie za autorką takiego rozumienia omawianej kategorii włącza w nią wyróżniane w tradycji szkoły lubelskiej aspekty: intelektualne, psychospołeczne (łącznie: psychiczne, psychospołeczne, społeczne), bytowe czy etyczne. Podział na aspekty uznaję za kryterium pomocnicze.

${ }^{13}$ Dokładny opis pism oraz działów, w których publikowane były listy, omawiam w innym tekście. Zob. M. Wacław ek: Czas na ... stereotyp chłopaka i jego modyfikacje (na przykładzie wypowiedzi młodzieży). W: A. Guzy, D. Jagodzińska, M. Wacławek, A. Zok-Smoła: Czas na... Język i dydaktyka w badaniach młodych naukowców. Katowice 2015, s. 225-239.

${ }^{14}$ Ibidem, s. $210-213$.

15 Wynik 334 jest sumą ekscerptów z następujących źródeł: F — 113; POP — 42; POL — 179. Analiza rynku prasowego oraz treści listów objętych badaniem utwierdziła mnie w przekonaniu, że niewielka liczba danych wyciągniętych z pism zagranicznych wydawców (POP) wpływa na większą wiarygodność rekonstruowanego (polskiego) obrazu. Zob. ibidem, s. 213. 
publikowane były w dawniejszej i nowszej prasie o polskiej proweniencji. Wskazana liczba stanowi punkt wyjścia obliczeń procentowych (w ujęciu autostereotypowym). Niewielka jest suma chłopięcych konkretyzacji $\left(44^{16}\right)$, co wiąże się z tym, że objęte analizą pisma w większości są czytane przez dziewczęta. W badanym materiale ujęcie heterostereotypowe można potraktować jedynie jako symboliczne (bez obliczeń procentowych). Ze względu na odmienną, bo „męską" perspektywę i takiż punkt widzenia, dane językowe wyciągnięte $z$ tej części listów wciąż wydają się ważne.

Ekscerpty zostały połączone w cechy deskryptorowe, które powiązano w syndromy (wiązki), a te w następujące grupy:

1. cechy i zachowanie społecznie uznawane za pozytywne;

2. cechy i zachowanie typowe dla adolescencji;

3. cechy i zachowanie społecznie uznawane za negatywne.

W badaniu i opisie zostały uwzględnione dane językowe występujące sporadycznie, co potwierdza ich wartość (uznanie możliwej zmienności stereotypowych obrazów oraz powściągliwość wobec jedynie ilościowej analizy materiału oraz zastosowanej techniki badania). Wykres 1 obrazuje udział procentowy poszczególnych grup syndromów w autostereotypie.

Wykres 1

\section{Grupy syndromów kategorii 'cechy charakteru i zachowanie' w autostereotypie DZIEWCZYNY}

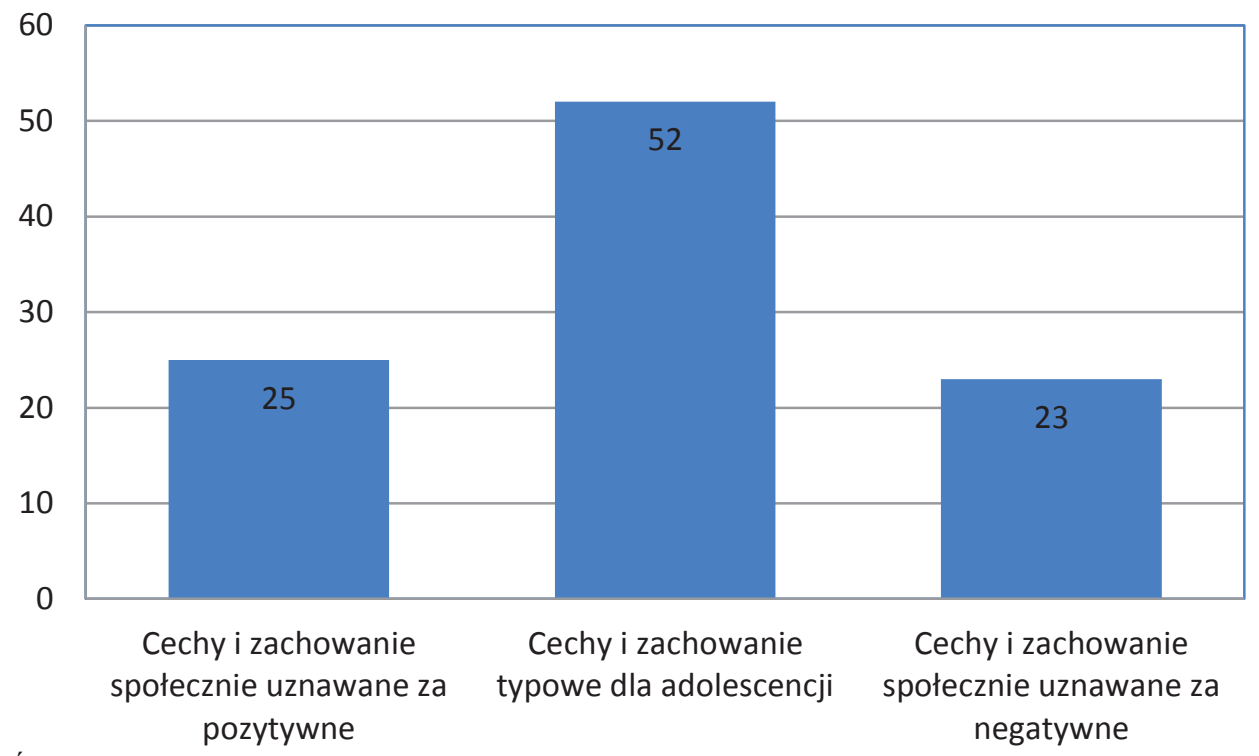

Źródło: Opracowanie własne.

${ }^{16}$ Udział liczbowy chłopięcych ekscerptów z objętych badaniem źródeł prasowych to: $\mathrm{F}$ - 8; POP -21 ; POL -15 . 


\section{Cechy i zachowanie społecznie uznawane za pozytywne}

W okresie dorastania kształtuje się świadomy wybór określonych wartości oraz postaw względem siebie i innych ludzi. W zebranym materiale listowym $25 \%$ wszystkich dziewczęcych konkretyzacji dotyczyło społecznie aprobowanych cech, postaw i zachowań. Na ten zestaw składają się następujące podgrupy:

1. różne zalety;

2. grzeczne, kulturalne zachowanie;

3. nieaprobowanie używek.

Zgodnie z rekonstruowanym wyobrażeniem „listowa” młoda kobieta postrzega siebie jako osobę posiadającą różne własności, wpływające na jej pozytywny odbiór (razem 10\% ekscerptów fasety 'cechy i zachowanie'). DzIEwCZYNA jest bowiem:

— sympatyczna, koleżeńska, miła, lubiana:

Jestem osobą sympatyczną i koleżeńską (P); [jestem — M.W.] życzliwą każdemu (F); bardzo miła (VG); fajna (C); Mnie wszyscy lubią (C).

— uśmiechnięta i zwariowana:

Uśmiechnięta $(\mathrm{VG})$; jestem optymistką $(\mathrm{F})$; uważana byłam za równą dziewczynę, wesołą (F); Jestem osóbką zabawną, zwariowaną i trochę zakręconą $(\mathrm{P})$.

- wartościowa:

Jestem osobą dość pewną siebie (F); jeżeli już coś umiem i wiem z całą pewnością, potrafię do upadłego bronić swoich racji (F); Poczucie odpowiedzialności każe nam tak postępować, aby pozostawać w zgodzie nie tylko z normami etycznymi, obowiązującymi w społeczeństwie, ale także z wewnętrzną, własną hierarchią wartości (F); szczera (VG); szanują moje oczytanie i elokwencję (C); inteligentna (C).

Duże znaczenie, potwierdzone wysokim udziałem procentowym ekscerptów, dla „listowej” dziewczyny ma grzeczne, kulturalne zachowanie (10\%), które albo już ją cechuje ( po prostu dziewczyny sa na poziomie — F), albo które chce lepiej opanować. W obrazie nakreślonym na podstawie listów z dawniejszej dziewczęcej prasy (F) często werbalizowana była chęć poznania zasad bon tonu: 
W jakiej kolejności przedstawiać dwoje ludzi? Głównie chodzi mi o sytuację koleżanka — kolega; Przy zawieraniu znajomości kto pierwszy chłopak czy dziewczyna - powinien powiedzieć swoje imię i „,bardzo mi miło", czy coś w tym rodzaju?; Kto pierwszy powinien wyciągnąć rękę na powitanie - chłopiec czy dziewczyna?; Czy wchodząc do windy w swoim bloku należy powiedzieć „dzień dobry” osobom, które się w niej znajdują?; Ojciec mojej przyjaciółki ze studiów jest profesorem na uczelni. [...] W domu przyjaciółki bywam bardzo często i naturalnie widuję ojca. Czy nawet na terenie domu powinnam zwracać się do niego: panie profesorze?

Wyrażane w listach zatroskanie sprawami związanymi z regułami etykiety ujawnia brak wiedzy na ten temat i odczuwaną potrzebę zmiany. Jak wynika z eksploracji, dla nowszej „listowej” dziewczyny kulturalne zachowanie łączy się nie tyle z poznawaniem i pozdrawianiem się, ile z dbałością i troską o sposób wysławiania (unikanie mody na anglicyzmy, potocyzmy, wulgaryzmy):

Gdy idę korytarzem szkolnym, zdaje mi się, że w polskim słowniku są same wulgaryzmy. A ja? Chyba jeszcze nikt nie usłyszał z moich ust przekleństwa. Bo nie chcę być taka jak wszyscy, chcę mieć własne (kulturalne!) zdanie (VG); Co jest fajnego w przeklinaniu? [...] Często słyszę wypowiadane przez nastolatki przekleństwa. [...] Nie będziecie przez to lepsi, a jeśli śmieciarska gadanina was dowartościowuje, to tylko pogratulować (VG); Nie kaleczmy naszego języka! Niech będzie taki, jaki być powinien! Z każdym użyciem takiego wyrazu [anglicyzmu — M.W.] niszczymy nasz język. Jak słyszę tych wariatów nastolatków na ulicy, robi mi się niedobrze. [...] pamiętajmy, że jak już ktoś stworzył nam piękny język polski, to może zachowajmy go jeszcze przynajmniej kilka pokoleń (P).

Przedstawiona w listach dziewczęca perspektywa sugeruje, że opisywane zjawiska są często doświadczane, co rodzi niezgodę i wiąże się z negatywną ewaluacją.

Przywołane w dawniejszych i nowszych konkretyzacjach postawy modelują obraz DZIEWCZYNY kulturalnej (umiejącej lub chcącej dobrze się zachować, dbającej o język i ceniącej dobre wartości). Taka postawa ujawnia z jednej strony cechy stereotypowo przypisywane kobiecie, przywiązującej wagę do dobrych relacji interpersonalnych oraz troszczącej się o warstwę językową, gdyż obdarzonej większą łatwością w operowaniu materiałem słownym ${ }^{17} . \mathrm{Z}$ drugiej zaś - przywołane ekscerpty zdradzają typowe dla okresu dojrzewania ,idea-

${ }_{17}$ Zob. A. Firkowska-Mankiewicz: Czy tak samo wychowujemy dziewczęta i chłopców?. W: Co to znaczy być kobieta w Polsce. Red. A. Titkow, H. Domański. Warszawa 1995, s. 45. 
listyczne standardy"18, postrzeganie świata w jednoznacznych (biało-czarnych) kategoriach.

Z perspektywą bezkompromisowej idealistki koreluje grupa wypowiedzi współtworząca obraz dziewczyny nieaprobującej używek, głównie tytoniu i alkoholu (5\%):

Nie palę, nie piję [...]. Mówią, że jestem niedzisiejsza (F); nigdy nie próbowałam papierosów. Nie ciągnie mnie do tego, ani nie imponuje (F); A według mnie można się świetnie bawić bez alkoholu! No i papierosy. Nikt, kto mnie zna, nie zaproponuje mi ,szluga”, bo będzie wiedział, że odpowiem mu: „Nie dzięki, truj się sam!” (VG); ja nie palę i moi kumple też, i tak też przecież może być dobrze (VG); Teraz śmiało odmawiam, kiedy ktoś proponuje mi, żeby się „napić” czy zapalić i wcale nie czuję się z tego powodu gorsza. Wręcz przeciwnie, czuję satysfakcję, że już nie zatruwam siebie, a inni nie traktują mnie przez to inaczej (VG); W mojej klasie są osoby, które biorą narkotyki albo piją na pokaz. [...] Ja się nie dałam i też mam przyjaciół (VG).

Również w rzadkich listach chłopców (ujęcie heterostereotypowe) odnotowano dane świadczące o tym, że młody mężczyzna pozytywnie percypuje i werbalizuje charakter i zachowanie DZIEWCZYNY (16 ekscerptów). Oto przykłady takiej konkretyzacji:

Miła (B); [... fajna (VG); całkiem fajna (T); Ona jest najfajniejszą dziewczyną, jaką dotychczas spotkałem i jaką można sobie wymarzyć (F); Moja dziewczyna jest bardzo fajna, niegłupia (F); Ta dziewczyna imponuje mi nie tylko swoją wiedzą, ale i inteligencją i charakterem (F); Ma dobry charakter i jest dla mnie pokrewną duszą (VG); To mądra, oczytana, przemiła dziewczyna. Jest bardzo ambitna i nie ma przewrócone w głowie, jak moje koleżanki (C); ona jest szczera (VG).

Opisy dotyczyły zarówno realnej, jak i wymarzonej partnerki. Z punktu widzenia chłopca dostrzegane są: dobre wychowanie, inteligencja i wiedza dziewczyny. Przede wszystkim lakonicznie stwierdza się, że jest fajna. Użycie tego wieloznacznego potocyzmu wydaje się bardzo praktyczne (ekonomiczne). Przymiotnik fajny — 'taki, który się podoba' — w przypadku opisu dziewczyny (w zależności od intencji mówiącego) określa zarówno jej wygląd, jak i charakter.

${ }_{18}$ Zob. A. Matczak: Zarys psychologii rozwoju. Podręcznik dla nauczycieli. Warszawa 2003, s. 227. 


\section{Cechy i zachowanie typowe dla adolescencji}

Zdecydowanie najwięcej danych językowych pochodzących z objętych badaniem listów publikowanych w prasie młodzieżowej rysuje obraz cech i zachowań DZIEWCZYNY w kontekście czasu dojrzewania (52\% ekscerptów). Niestabilność emocjonalna i konfliktowy charakter adolescencji mogły prowadzić do różnych, mocno odczuwanych i tak też werbalizowanych problemów ${ }^{19}$. W ten sposób profilowaną kreację szeroko rozumianych aspektów psychospołecznych współtworzą następujące „odłamki”:

— dziewczyna jest nieśmiała;

- dziewczyna jest dziecinna;

— dziewczyna ma obniżony nastrój;

— dziewczyna chce być poważnie traktowana przez dorosłych.

Jak podkreśla Leon Niebrzydowski: „Okres dorastania charakteryzuje się silną potrzebą nawiązania kontaktów społecznych i własnej autoafirmacji” ${ }^{20}$. Brak pełniejszej realizacji tych pragnień rodzi sytuacje problematyczne. Nie najmniejszy odsetek ekscerptów dotyczy wstydliwości. Dziewczyna najczęściej expressis verbis określa siebie jako osobę nieśmiałą (9\%):

Jestem nieśmiała (VG); Też jestem bardzo nieśmiałą osobą i przeszkadza mi to (VG); jestem cicha jak mysz. [...] To wszystko zaś jest skutkiem mojej chorobliwej nieśmiałości, a wręcz fobii społecznej (VG); jestem bardzo nieśmiała. Pojawia się to wtedy, kiedy jestem w obecności osoby starszej ode mnie (VG); Niestety, jestem nieśmiała i mam problem z zawieraniem nowych znajomości (B); jestem nieśmiała w stosunku do dziewczyn, nie mówiąc już o płci przeciwnej (VG); jestem [...] nieśmiała... Przez co wszyscy faceci myślą, że gram niedostępną! (T); Jestem nieśmiała, a na dodatek boję się, że mnie odrzuci, bo jestem młodsza [o dwa lata - M.W.] (VG); Teoretycznie mogłabym do niego podejść, spytać o jakąś mało istotną rzecz. Problem w tym, że jestem nieśmiała (C); Moje problemy na pewno wydadzą się Redakcji banalne, ,typowe dla wieku dorastania”, ale ja jestem przekonana, że wynika to nie $\mathrm{z}$ wieku, lecz z mojego charakteru i usposobienia. Jestem, a właściwie byłam, bo to już stopniowo mija, nieśmiała $(\mathrm{F})$.

19 Szczegółowo o tej fazie rozwoju osobniczego piszę w innym tekście. Zob. M. Wacławek: Czas na... stereotyp chłopaka i jego modyfikacje (na przykładzie wypowiedzi młodzieży). W: A. Guzy, D. Jagodzińska, M. Wacławek, A. Zok-Smoła: Czas na... Język i dydaktyka..., s. $200-207$.

${ }^{20}$ L. Niebrzydowski: O poznawaniu i ocenie samego siebie: na przykładzie młodzieży. Warszawa 1976, s. 63-64. 
Różne mogły być wskazywane przez czytelniczki sytuacje obnażające niejednokrotnie wyolbrzymianą wstydliwość; najczęściej dotyczyły kontaktów interpersonalnych, zwłaszcza z rówieśnikami płci przeciwnejej. Opisywany sposób konceptualizacji ukazuje DZIEWCZYNĘ jako osobę niedowartościowaną, oceniającą się jako gorszą od innych (koleżanek i kolegów). Nieśmiałość uznana została za cechę ujemną.

Na tym tle jako wyjątkowa, świadoma i dojrzała jawi się następująca wypowiedź:

Chcę zabrać głos w sprawie nieśmiałości. Sama jestem nieśmiałą osobą, ale nie przeszkadza mi to zbytnio. [...] Zaakceptowałam się taką, jaką jestem. Już nie przeszkadzają mi rumieńce pojawiające się w chwili poznania nowej osoby czy np. proszenia kogoś o coś. Zauważyłam nawet, że ludzie odnoszą się do mnie życzliwiej, chyba właśnie dlatego, że jestem taka nieśmiała. Inaczej podeszłam do mojej ,wady” i uczyniłam z niej zaletę, a konkretniej cząstkę tego, co ludzie zwą urokiem (VG).

W zależności od żeńskiego (dziewczęcego) i męskiego (chłopięcego) punktu widzenia opisywany atrybut jest inaczej wartościowany. Jak pokazują werbalizacje zarejestrowane w listach POP (4 ekscerpty), dla „listowego” chłopaka nieśmiałość dziewczyny jest jej wielką zaletą, czymś atrakcyjnym. To dodaje mu odwagi, zachęca do działania: jest bardzo nieśmiała, dlatego się w niej zakochatem $(\mathrm{T})$.

W rekonstruowanym wizerunku DZIEWCZYNY bardzo mocno uwypukla się syndrom obniżonego nastroju (współtworzy go aż 38\% wszystkich ekscerptów). Duża liczba listów ujawniających tendencję do złej kondycji psychicznej nie powinna dziwić - jedną z pobudek do napisania do redakcji pisma mogły być problemy, z którymi czytelniczka sama nie chciała lub nie umiała sobie poradzić. Piszące podawały różne przyczyny swojego złego stanu psychicznego, najczęściej były nimi: brak przyjaciół, poczucie braku akceptacji ze strony rówieśników, problemy w domu (w tym: rozwód rodziców, alkoholizm), nieszczęśliwa miłość, kłopoty w szkole, rozterki związane z przyszłością czy niezadowolenie ze swojego wyglądu.

Zgodnie z konceptualizacją tego syndromu dziewczyna czuje się samotna, (osamotniona):

Jestem bardzo samotna (VG); czuję się ogromnie (nie przesadzam) samotna (F); jestem taka samotna... Nie mam z nikim bliskiego kontaktu (C);

${ }^{21} \mathrm{~W}$ profilu partnerki został przedstawiony inny, związany z relacją damsko-męską, aspekt zachowania ,listowej” dziewczyny — ,przedsiębiorczej”, „,biorącej sprawy w swoje ręce”, a więc śmiałej. Zob. M. Wacławek: Przemiany profilu partnerki..., s. 213-215. 
Szkoda, że nie ma sklepów z przyjaciółkami, bo ja bym nawet wzięła taką z posezonowej wyprzedaży. A tak na serio, to czuję się samotna, nie mam z kim pogadać o zwykłych babskich sprawach, nie mam z kim spędzić sobotniego popołudnia albo poprzymierzać ciuchów (VG); Czuję się osamotniona. Próbowałam zwierzyć się przyjaciółce, jednak ona dała mi do zrozumienia, że nie ma ochoty ze mną o tym rozmawiać (C); jestem przez wszystkich opuszczona $(\mathrm{F})$.

Osamotnienie niejednokrotnie wiązało się z brakiem bliskich przyjaciół, ważnych szczególnie dla dziewcząt (potrzeba zwierzania się, bycia wysłuchanym, empatii). W obliczu problemów tak profilowana DZIEWCZYNA:

- boi się:

Boję się przyszłości. Ciągle napada mnie myśl, że nie poradzę sobie w życiu (VG); Zaczęłam się bać wszystkich ludzi. [...] Boję się początku roku szkolnego, boję się powrotu do klasy (F); bałam się jej przyznać do tego, co narobiłam w szkole i do tego, co się ze mną dzieje (F); Boję się, że klasa będzie na mnie odreagowywać frustracje po lekcjach z ciotkąa2 (C); Ale tak się boję, czy nasze uczucie przetrwa tę próbę (F); Panicznie boję się jego odrzucenia (C).

- jest załamana:

Jestem załamana (F); Jestem załamana! Nie potrafię pogodzić się z tym, że moja rodzina się rozpada (B); Zupełnie się załamałam. [...] Przez tydzień siedziałam w domu jak otępiała, płakałam... (T); na półrocze wylądowałam z dwoma dwójami. I kompletnie się załamałam (VG); Przed całą szkołą zostałam ośmieszona. I nie mogłam sobie z tym poradzić, byłam kompletnie załamana (VG); Jestem załamana! Od kilku miesięcy kocham Cody'ego Simpsona. Wiem, że moje uczucie do niego nie ma sensu, ale nie potrafię przestać o nim myśleć (B); Jestem załamana! Przez moje bardzo małe piersi nie mogę nosić bluzek z dekoltem (B).

Bez względu na to, jak opisywane problemy odbierają ,inni”, z punktu widzenia piszącej młodej kobiety przyczyna złej kondycji psychicznej jest znacząca i może powodować poważne następstwa. „Listowa” DZIEWCZYNA przyznaje się, że zobojętniała na otoczenie, stała się apatyczna, ma stany depresyjne, a nawet myśli samobójcze:

22 Przy okazji pisząca odwołuje się do profilu starej panny (nauczycielki): moja ciotka to specyficzna osoba. Jest bardzo surowa. Prawdę mówiac, jest singielka po czterdziestce (czyli stara panna) i nienawidzi dziewczyn. 
Ciągle jestem przygnębiona, przestałam spotykać się ze znajomymi, a wolny czas spędzam w swoim pokoju, słuchając smutnych piosenek i płacząc. Czuję, że moje życie straciło sens... (B); w ogóle nie mam chęci czegokolwiek robić. Nie mam chęci do życia. Rano zmuszam się, by wstać i iść do szkoły (VG); Od paru dni nie chodzę do szkoły, nie mogę się uczyć ani jeść. Kompletnie oderwałam się od znajomych. Nie mam ochoty nawet pisać z nikim (C); Miewam doły i nie potrafię w tym czasie powstrzymać się od nieuzasadnionego płaczu. Czasami prześladuje mnie myśl, że nikt w moim otoczeniu mnie nie lubi (C).

Wydaje mi się, że ciągle mam depresję... (B); Zrozumiałam, że moja depresja była częściowo moim zaniedbaniem — patrzyłam tylko na to, co mi nie wychodziło (VG).

[...] od około miesiąca mam myśli samobójcze (VG); Ja miewam myśli samobójcze, które od czasu do czasu powracają nawet teraz (C); Nikt po mnie nie będzie płakał. Mam ładną siostrę, więc ona pocieszy rodziców. Naprawdę nie wiem, czy jest sens żyć. Coraz częściej myślę o tym, że gdybym wreszcie umarła, moje cierpienia by się wreszcie skończyły (VG).

Ekscerpty rysujące obraz dziewczęcych depresji i myśli samobójczych informują o chwiejnym stanie psychicznym i emocjonalnym nastolatek, ujawniają ich subiektywny punkt widzenia, rzeczywistość ukazaną bardzo fragmentarycznie, są zarazem wyrażanym w listach jaskrawym sygnałem prośby o pomoc ${ }^{23}$.

Mimo zarejestrowania $\mathrm{w}$ badanym materiale jedynie trzech chłopięcych wypowiedzi na temat słabej kondycji psychicznej DZIEWCZYNY, ekscerpty te są istotne. $Z$ perspektywy chłopca w ten sposób modelowana DZIEwCZYNA ma tendencję do nadmiernego analizowania siebie i swoich relacji (w tym hiperbolizowania, jego zdaniem, pseudoproblemów):

Narzeka, że czuje się nielubiana, że nie ma chłopaka, że nie może znaleźć prawdziwej przyjaciółki. [...] Myślicie, że ktoś naprawdę zmagający się z życiem zastanawia się, czy Kasia lub Basia go lubi, czy tylko udaje? (VG).

Również młodzi mężczyźni wyrażają dziewczęce tendencje samobójcze, co w ich opinii mogło być sposobem perswazji (szantażu) lub reakcją na zachowanie chłopaka:

${ }^{23}$ Pocieszające są listy dziewcząt informujące o tym, że po etapie skrajnego braku akceptacji siebie (czasem nawet próbach samobójczych), apatii, traumatycznym przeżyciu, może nastąpić autoterapia (tego typu wypowiedzi odnotowałam w listach VG: 8 razy i C: 1 raz). Ponadto w tekstach publikowanych w VG (5 razy) czytelniczki przyznały, że w sytuacji, gdy nastolatka nie radzi sobie z problemami, należy udać się do specjalisty. 
[...] powiedziały, że jeśli im nie pomogę, to się chyba zabiją (C); Ona chciała przeze mnie nawet popełnić samobójstwo (VG).

Warto przywołać fragment listu czytelniczki, opublikowanego w dziale „Kamykowa poczta” (VG). Wypowiedź ta jest odpowiedzią na przywołaną wcześniej chłopięcą krytykę (pozornie) błahych problemów nastolatków, a raczej nastolatek:

Według mnie, lepiej jest otwarcie mówić o swoich drobnych zmartwieniach niż gromadzić je w sobie i czekać, aż urosną one do rangi wielkiego kłopotu. Oczywiście, to, że ludzie nie mają pracy, chorują, to są poważne problemy, ale nie można ich zestawiać i porównywać z problemami dzisiejszej młodzieży; czemu brak chłopaka, przyjaciół czy uczucie bycia nielubianym miałoby mieć mniejszy wpływ na nasze samopoczucie. Nawet tak błaha sprawa, jak pogoda, może uczynić nas nieszczęśliwymi, a w szczególności w tym wieku. Dorastamy i jest to naprawdę trudny okres, w którym poszukujemy naszego własnego ja. [...] nie zapominajmy przy tym, że nasze problemy są również ważne — dla nas samych.

Kłopoty DZIEWCZYNY - czy ogólnie młodych — są istotne. Świadczą o tym choćby podjęte próby ich upubliczniania w prasie młodzieżowej.

Do odtwarzanego obrazu życia wewnętrznego DZIEWCZYNY i jego zewnętrznych przejawów należy jeszcze zaliczyć dwa słabiej ujawnione (rzadko werbalizowane) syndromy. Jeden z nich — zarejestrowany tylko w nowszym materiale pochodzącym z pism o polskiej proweniencji (POL) — dotyczy postrzegania DZIEWCZYNY jako osoby dziecinnej (3\%). Ocenianie swojej dziecinności mogło być neutralne lub negatywne:

A ja uważam, że mam prawo taka być. Kiedy mam się nacieszyć dzieciństwem, jak nie teraz (VG); Problem w tym, że wstydzę się swojego powrotu do Krainy Dzieciństwa (C).

Treść listów wyrażała również to, że DZIEWCZYNIE rówieśnicy przypisywali ujemnie wartościowaną infantylność:

Oni uważają, że jestem strasznie dziecinna, ale to nieprawda... (VG); Moje koleżanki uważają, że jestem dziecinna. Bo lubię kreskówki, różowy kolor, chodzę z rodzicami do ich znajomych i... nie mam chłopaka (VG).

Również z chłopięcej perspektywy DZIEWCZYNA bywa postrzegana jako osoba infantylna (1 ekscerpt), co było negatywnie oceniane: 
Gdy jest ze swoją przyjaciółką, dziecinnieje w oczach. Ostatnio nie mogła się ze mną spotkać, bo oglądała Króla Lwa II (ona ma 17 lat!) (C).

W młodości kształtuje się krytycyzm myślenia i tego dotyczy drugi z ubogo zarysowanych syndromów. Z ekscerptów zebranych tylko z dawniejszych listów (F) wyłania się dziewczęca (przezwyciężająca dziecinność) potrzeba poważnego (partnerskiego) traktowania jej przez dorosłych (2\%):

Czy starsi mają prawo bezkarnie obrażać młodych, tylko dlatego, że są młodzi?; I jak tu wierzyć dorosłym, że każdy powinien mieć i wygłaszać własne zdanie? $\mathrm{Z}$ moich doświadczeń wynika, że mieć to może i można, ale wygłaszać to już raczej nie należy $(\mathrm{F})$.

Młoda kobieta buntuje się przeciw krzywdzącej postawie dorosłych, którzy jej — czy też generalnie młodych — nie rozumieją i są autorytarni.

\section{Cechy i zachowanie społecznie uznawane za negatywne}

W odtwarzanym na podstawie danych listowych językowo-kulturowym wyobrażeniu DZIEWCZYNY duży odsetek ekscerptów (23\%) współtworzy listę niechlubnych cech i zachowań. Pokazuje to krytyczny stosunek piszących do samych siebie oraz do swoich rówieśnic. W zebranym materiale nazwy cech wyrażone przymiotnikami były odnotowywane niezwykle rzadko (1\%). Zgodnie z tymi danymi „listowa” DZIEwCZYNA: Często jest niemiła (VG) oraz pozbawiona zalet intelektu: gtupia (C).

Prawie wszystkie konkretyzacje opisujące nieakceptowane dziewczyńskie zachowanie językowo koncentrowały się wokół nazywających określone działanie konstrukcji czasownikowych. „Listową” DZIEWCZYNĘ wiele denerwuje (7\%):

Wszystko mnie też denerwuje. [...] nie mogę nad sobą zapanować. Ciągle jestem jakaś zdenerwowana (VG); Ciągle mi mówi, że moje rodzeństwo takie nie było, co mnie bardzo denerwuje (VG); Od dłuższego czasu zaczyna denerwować mnie przyjaciółka (VG); Strasznie denerwują mnie grubi ludzie. Wprost nie mogę na nich patrzeć (VG); się [...] denerwuje, gdy coś idzie nie tak $(\mathrm{VG})^{24}$.

${ }^{24}$ Inne jednostkowe ekscerpty należące go tej grupy, językowo wyrażające stan mocnego zdenerwowania za pomocą różnych środków, to: Wkurza mnie moja klasa... (VG); Wkurzyłam się 
Irytacja wiąże się z konfliktogennością, dlatego w ten sposób modelowana DZIEWCZYNA kłóci się (z rodzicami, rodzeństwem, grupą rówieśniczą, chłopakiem itd.; 4\%):

Prawie stale się kłócimy (F); Nie wiem dlaczego, ale ciągle kłócę się z rodzicami (VG); Miesiąc temu pokłóciłyśmy się, tak naprawdę to poszło o głupstwo (F); wiadomo, jak to wśród dziewczyn — kłótnie, płacze, histerie itp. (F).

Dziewczyna przyznaje, że powody konfliktu (zwłaszcza z rodzicami) mogą być błahe i ona sama może je prowokować.

Analizowane teksty ujawniają intensywność stanów emocjonalnych związanych z uczuciem gniewu i agresji. Emfaza wyrażona była m.in. za pomocą odpowiednich (zwykle kolokwialnych) przysłówków: strasznie się z nim pokłóciłam; Strasznie mnie to denerwuje; Strasznie mnie to wkurzyto; maksymalnie mnie irytuje; Bardzo się złoszczę. Okazuje się, że opisywany stan może być permanentny: Ciagle jestem zła; Ciagle jestem jakaś zdenerwowana; ciagle kłócę się z moim chtopakiem i rodzicami; nie ma dnia, którego nie zaczniemy od porządnej kłótni o byle co; Od dłuższego czasu zaczyna denerwować mnie przyjaciótka. Nagromadzone słownictwo i związane z nim emocje towarzyszące piszącym wyraźnie pokazują typowe dla okresu adolescencji: bunt, oznaki dezintegracji osobowości i łączące się z tym zaburzenia w relacji z otoczeniem. To zarazem kolejny sygnał subiektywnego, typowego dla wieku młodzieńczego, oglądu rzeczywistości, pokazywania wyłącznie własnej perspektywy i uznawania jej za jedyną bądź najważniejszą; wyrażany w języku brak umiejętności kontrolowania emocji, podejścia bardziej racjonalnego, niezgody na zastaną rzeczywistość — to cechy typowe dla młodych.

Opisywane przykre zachowania DZIEWCZYNY dotyczą nie tylko okazywania irytacji czy gniewu, ale również obgady wania (4\%) - stereotypowo przypisywanego osobom płci żeńskiej. Konkretyzacje dotyczące tej cechy udało się zebrać tylko z materiału POP i częściowo VG. Zgodnie z treścią listów informacje o dziewczyńskim niechlubnym rozpowszechnianiu różnego rodzaju pogłosek dotyczyły raczej nie samej piszącej, lecz jej koleżanek:

Agata obgaduje mnie za moimi plecami (B); Obgadują mnie i mojego chłopaka, naśmiewają się z nas (VG); po ich wyjeździe zaczęło się obgadywanie, że beznadziejni, że jak można się tak ubierać itd. [...] Mam wrażenie, że o mnie też nic dobrego nie mówią... (VG).

na mamę, ale ona twierdzi, że niepotrzebnie robię aferę (B); Jestem na niego wściekta... (T); Nie moge jej tego darować. Gdy o tym myśle, szlag mnie trafia (C); Byłam i jestem oburzona cenami za takie nic $(\mathrm{F})$; irytuje mnie, gdy rozmawia ze mna o głupstwach $(\mathrm{F})$. 
Pojechałam po wszystkich, którzy mi podpadli. Opisałam historię przyjaciółki, nazwałam jej faceta nadętym burakiem, a ją samą naiwną idiotką. Potem obgadałam laski z mojej paczki. Zośkę określiłam mianem snobki i obśmiałam inne panny, że słuchają jej jak pieski swojej pani $(\mathrm{T})^{25}$.

W grupie syndromów współtworzących autoportret niecnych działań „listowej” DZIEWCZYNY jest również kłamanie/okłamywanie (4\%). Krytyka takiego działania dotyczy zarówno samej siebie, jak i koleżanek:

Czuję wstręt do siebie i do ludzi, których okłamuję (F); Okłamuję wszystkich, wymyślam różne bzdury, kłamię, że jadę do babci, do koleżanki, do kina, żeby z nim spędzić trochę czasu (VG).

Ania kłamie na każdym kroku. Bez przerwy opowiada o nowych chłopakach, przeżyciach miłosnych, znajomościach przez Internet (VG); Moja przyjaciółka to klasyczna mitomanka. Gdy tylko, nawet przypadkowo, spotka jakiegoś chłopaka, uważa, że on się na nią gapił, że wzroku od niej nie mógł oderwać (C).

Z punktu widzenia piszących kłamstwo może być oznaką ucieczki od problemu - jest swoistą porażką moralną, wiążącą się z brakiem zaufania czy bezpieczeństwa; może być także próbą kreowania nowego (lepszego w mniemaniu piszącej) wizerunku ${ }^{26}$.

Do listy autostereotypowych, nieprzynoszących chluby zachowań zaliczyć należy również przywiązanie do używek (3\%). Głównie wspominano o spożyciu alkoholu i tytoniu, co najczęściej językowo wyrażano za pomocą czasowników „palić” i „pić”. Krytykowane zachowanie, podobnie jak okłamywanie, mogło dotyczyć rówieśnic lub samej piszącej:

Jedna chodziła wciąż pijana (F); jedna strasznie dużo pali (F); Kolega częstuje mnie papierosem, ja odmawiam, a ktoś trzeci wtrąca się i mówi: „Każda współczesna dziewczyna pali” (F).

Wciągnęłam się w tzw. „złe towarzystwo”. Myślałam, że dzięki temu zmienię swój wizerunek, że z nudnej „kujonki” (!) stanę się fajną dziewczyną. Zaczął się alkohol i papierosy (VG).

${ }^{25}$ Działanie opisane w ostatnim cytacie musiało wiązać się z konsekwencjami: No i nie sqdziłam, że Iwona komuś to powtórzy. Tymczasem ona zamieściła nasza rozmowe na swoim blogu! „Nie należy ufać nikomu” - tak zatytułowata wpis. A potem rozesłała linki do niego wszystkim znajomym, których adresy znała [...]. Codziennie zadaję sobie pytanie, dlaczego Iwona zachowała się tak podle. [...] Czemu zrobiła mi takie świństwo?

${ }^{26}$ Kategorie prawdy i kłamstwa są zjawiskami interesującymi badawczo, w przypadku analizy języka młodzieży szerzej na ten temat pisała Małgorzata Karwatowska. Zob. M. Karwatowska: Prawda i kłamstwo w języku młodzieży licealnej lat dziewięćdziesiatych. Lublin 2001; Eadem: Autorytety w opiniach mtodzieży. Lublin 2012, s. 81—95. 
Stosowanie używek zwykle wynikało ze źle pojętej potrzeby akceptacji ze strony grupy rówieśniczej (jest to myślenie typu: jeśli będę pić, palić, będę ,fajniejsza", bardziej lubiana, a także atrakcyjniejsza dla chtopaka).

Prawie połowa ekscerptów z (rzadko odnotowywanych) listów chłopięcych (dokładnie 20) współtworzy wycinkowy negatywnie wartościowany obraz charakteru i zachowania DZIEWCZYNY. Rekonstruowane w autostereotypie grupy syndromów współtworzące postawy społecznie uznawane za niedobre w ujęciu heterostereotypowym zostały powtórzone, uzupełnione i wzbogacone o „chłopięcą" perspektywę. Z punktu widzenia „listowego chłopaka” w ten sposób konkretyzowana dziewczyna może go:

— ignorować:

Na następne trzy listy nie odpisała (F); Ostatnio nie mogła się ze mną spotkać, bo oglądała Króla Lwa II (ona ma 17 lat!) (C); Usłyszałem tylko: dziękuję, nie mam czasu, jestem zajęta. Tak jakby kpiła sobie ze mnie (F).

- nie doceniać:

Chciałem jej kiedyś pokazać stare książki z kapitalnymi rysunkami. To ją nudzi. Woli kiepską kawę, niż rozpamiętywanie, jak kiedyś patrzono na świat $(\mathrm{F})$.

- deprecjonować:

O wszystko się czepia - że mało czytam, nie jestem wrażliwy, nic mnie nie interesuje, nie umiem zrobić lasagni [!]. Ogólnie jestem do niczego (C).

W takim ujęciu DZIEWCZYNA jest osobą mającą „,babską” tendencję do „czepiania się", kłótliwości i hiperbolizacji tego, co ją denerwuje:

Codziennie [...] robi awantury o byle co! Nawet nie da rady spokojnie z nią porozmawiać (VG); [...] jak każda baba nie możesz być zadowolona ze wszystkiego. Zawsze szukacie dziury w całym i zawsze jakąś znajdziecie. [...] jesteś czepliwa (VG); Boję się, że ona zrobi z tego wielką aferę (B).

W eksplorowanym chłopięcym materiale językowym (tylko na przykładzie danych z T) werbalizowana była nie tyle skłonność do plotkowania DZIEWCZYNY, ile stereotypowo jej przypisywana potrzeba zwierzania się innym (koleżance, koleżankom). Oto przykłady takiej konkretyzacji:

Jeśli moja dziewczyna papla o naszych sekretach swojej najlepszej przyjaciółce, ona może potem powtórzyć to innym dziewczynom i koniec koń- 
ców wszyscy będą wiedzieć, co dzieje się w naszym związku; Mam wrażenie, że zwierzanie się z miłosnych doświadczeń jest domeną dziewczyn. Tak jak chodzenie razem do toalety ${ }^{27}$.

Zdarza się również, że $\mathrm{w}$ chłopięcym postrzeganiu dziewczyna jest konformistką:

Ale ona uważa, że w sobotę trzeba gdzieś wyjść — na prywatkę, do kina, do kawiarni. Byle nie w domu, byle tak jak wszyscy $(\mathrm{F})^{28}$.

\section{Podsumowanie}

Kulturowo, a zatem i stereotypowo, kobietę, nie tylko tę młodą, postrzega się przez pryzmat jej aparycji ${ }^{29}$, jednak, jak stwierdza jedna z czytelniczek: $w y-$ glą nie jest najważniejszy, bo ważniejsze jest nasze wnętrze (VG). Analizowana faseta w rekonstrukcji językowo-kulturowego konceptu jest istotna:

Czynności, jakie wykonuje opisywany podmiot, stany, jakim podlega, jego działanie sprawcze określają go dokładniej, wskazując jednocześnie relacje $\mathrm{z}$ otoczeniem ${ }^{30}$.

Zebrany na potrzeby artykułu materiał listowy opisujący odtwarzany komponent wyobrażenia DZIEWCZYNY daje ciekawy, choć z natury rzeczy niepełny obraz, co zachęca do dalszych badań zarówno listowych, jak i uwzględniających inne typy danych językowych.

Stereotyp odtwarzany na podstawie listów pochodzących z prasy młodzieżowej z różnych okresów — z końca czasu PRL oraz przełomu pierwszej dekady XXI wieku, które dzieliła nie tylko różnica czasowa, ale też odmienność kultu-

27 Wypowiedzi młodych mężczyzn ujawniają jeszcze jedną ważną cechę, tym razem chłopaka - on chce być ,publicznie” chwalony: Dopóki panna mnie chwali albo opowiada kumpelom neutralne rzeczy, nie mam z tym żadnego problemu. Gorzej, kiedy zaczyna nawijać o moich słabszych stronach.

${ }^{28}$ Więcej (nie tylko) negatywnie ocenianych postaw dziewczyny stricte w kontekście jej relacji z chłopakiem (sympatią) zostało przedstawionych w innym tekście. Zob. M. Wacławek: Przemiany profilu partnerki..., s. 209-222.

29 Zob. Eadem: Kategoria wygladu w językowo-kulturowym (auto)stereotypie dziewczyny. W: „Z Teorii i Praktyki Dydaktycznej Języka Polskiego”. T. 25, s. 141-142.

${ }^{30}$ B. Niesporek-Szamburska: Stereotyp czarownicy i jego modyfikowanie. Na przykładzie tekstów dzieci i wypowiedzi dziecięcych. Katowice 2013, s. 99. 
rowa - ujawnił wiele elementów zbieżnych. Wyróżnione trzy grupy syndromów: cechy i zachowanie społecznie uznawane za pozytywne, cechy i zachowanie typowe dla adolescencji oraz cechy i zachowanie społecznie uznawane za negatywne, współtworzą trzy modele w rekonstruowanej fasecie obrazu DZIEWCZYNY. Pierwszy z nich profiluje ciążący ku idealności model osoby uśmiechniętej i kulturalnej (miłej, koleżeńskiej, optymistycznej, umiejącej się zachować, szanującej tradycyjne wartości, nieprzychylnej używkom, dbającej o język). Taki wizerunek współtworzy 25\% ekscerptów. Ponad połowa danych językowych uzyskanych z dziewczęcych listów buduje portret młodej kobiety borykającej się z różnymi problemami okresu dojrzewania. Tak profilowana dziewczyna jest nieśmiała, czuje się osamotniona, boi się, bywa załamana, miewa stany depresyjne, a nawet myśli samobójcze. Wszystkie te zachowania werbalizują z perspektywy dziewczyny trudne przeżycia, które są typowe dla okresu przejściowego od dzieciństwa do dorosłości. Wysoki odsetek ekscerptów mocno zarysowujący ten obraz jest zrozumiały, również ze względu na podstawę materiałową eksploracji - młodzi wysyłali listy do czasopisma, często prosząc o radę. Liczebnie niewiele mniejsze od kreacji idealizującej jest ujęcie kontrastywne - negatywnie wartościowany model dziewczyny niekulturalnej (kłótliwej, agresywnej — gdyż wiele rzeczy ją denerwuje — kłamliwej i stosującej używki). Wysoka częstotliwość tak konceptualizowanego obrazu również nie powinna dziwić — gdyby dziewczęce zachowania i postawy były „normalne”, standardowe, niewarte byłyby przedstawienia w korespondencji.

Pomimo symboliczności (bo rzadkości) ekscerptów współtworzących ujęcie heterostereotypowe, okazało się ono znaczące. Chłopięcy punkt widzenia, i związana z nim perspektywa oglądu, wpływał na jakość postrzegania. W objętym badaniem materiale listowym różnice między auto- a heterostereotypowym werbalizowanym postrzeganiem dotyczyły w pewnym stopniu ilości oraz jakości dziewczęcych cech, a także ich ustrukturowania i waloryzowania. Profilowana w męskich listach DZIEWCZYNA może się podobać, być uważana za fajną (nie tylko w kontekście fizycznym) i ceniona. Wyraźnie widać różnicę w sposobie konceptualizacji nieśmiałości, którą chłopak — inaczej niż dziewczyna uznaje za zaletę, cechę stymulującą jego aktywność. Neutralnie lub negatywnie postrzegana dziecięcość partnerki przez młodego mężczyznę odbierana jest jedynie krytycznie. Bywało, że chłopięce spojrzenie cechowała większa zdroworozsądkowość - zwracano uwagę na dziewczęcą tendencję do wyolbrzymiania swoich problemów. W ujęciu krytycznym, rysującym model dziewczyny niekulturalnej, zarejestrowane chłopięce ekscerpty implikowały jednak poczucie urażonej „męskiej” dumy, młoda kobieta mogła bowiem ignorować chłopca, nie doceniać go, a nawet deprecjonować. Podkreślono typowo „babskie” zwierzanie się koleżankom ze wszystkiego, co dzieje się z związku, czepianie się, ograniczanie wolności, a nawet szantażowanie. 
Przedstawiony obraz wydaje się dobrze skrystalizowany. Różnice w sposobie konceptualizacji i przekazywanych treściach na przestrzeni trzydziestu lat nie były duże. Z pewnością język nowszych listów odznaczał się bardziej kolokwialnym stylem (slangiem młodzieżowym). $Z$ nowszego materiału wyłoniono zdecydowanie więcej ekscerptów współtworzących model dziewczyny borykajacej się z różnymi problemami okresu dojrzewania ${ }^{31}$, co może wynikać z wielu czynników, m.in. z (obiegowej) opinii o tendencji do zmniejszającej się odporności psychicznej młodzieży oraz zwiększającego się relatywizmu uznawanych wartości. Różnica jakościowa pojawiła się jedynie w słabo zarysowanych syndromach dziewczęcej dziecinności versus dorosłości (tu rozumianej jako chęć poważniejszego traktowania). Jedynie w nowszym materiale listowym zarejestrowano konceptualizowaną dziecinność dziewczyny, co można wiązać choćby ze współczesnym wydłużaniem się okresu niedorosłości ${ }^{32}$. Potwierdzeniem takiej tendencji jest sygnalizowany tylko w ekscerptach $\mathrm{z}$ dawniejszej prasy syndrom dziewczyny myślacej krytycznie, chcącej poważniejszego traktowania jej (czy szerzej młodzieży) przez autorytarnych dorosłych ${ }^{33}$.

Niech swoistego rodzaju podsumowaniem niniejszej analizy będzie wypowiedź jednej z czytelniczek:

Nasze życie wewnętrzne? Proszę mi uwierzyć, jest i to głębokie, pełne wzlotów i upadków, czyli ochów i dołków (F).

${ }^{31}$ Tę grupę syndromów współtworzy 38\% wszystkich ekscerptów w fasecie 'charakter i zachowanie' dziewczyny; udział procentowy danych z poszczególnych źródeł to: $\mathrm{F}-8 \%$; POP $6 \%$; POL $-24 \%$.

${ }^{32}$ E. Krzaklewska: Wzory wchodzenia $w$ dorostość z perspektywy genderowej. W: Kalejdoskop genderowy. W drodze do poznania ptci społeczno-kulturowej w Polsce. Red. K. Slany, B. Kowalska, M. Ślusarczyk. Kraków 2011, s. 251.

${ }^{33}$ Chęć partnerskiego traktowania przez dorosłych w listach z końca okresu PRL wynikała również z ówczesnej sytuacji. Postulat nieprotekcjonalnego podejścia do młodych był pośrednim sygnałem nadchodzących zmian i problemów, którymi wówczas żyło polskie społeczeństwo: Strajku wam się może zachce — krzyczała kierowniczka [internatu — M.W.]. Jak złodziei szukacie, to jedźcie do Warszawy [...]. Napisałam to wszystko, aby wykazać, że my dziewczyny myślimy, ale niektórzy dorośli nadal [...] nie chca tego przyjąć do wiadomości. Dlatego zaktadamy maski, żeby na naszych twarzach nie było widać ani obojętności, ani sceptycyzmu, ani nadziei. Najbezpieczniejsza jest uniwersalna maska grzecznej, potulnej aprobaty. Ekscerpty zebrane z nowszej prasy młodzieżowej, ze względu na odmienne realia, siłą rzeczy nie profilują takiego obrazu. Niemniej jednak analizowane przeze mnie dane z nowszych pism mają już wartość historyczną. Eksplorację warto powtórzyć za kilka lub kilkanaście lat. Być może postawy opisywane w listach do „Filipinki”, w związku z dynamicznie zmieniającą się rzeczywistością, nie będą — niestety — aż takie odległe. 


\section{Bibliografia}

Bancerz M.: Dziewczęta widza siebie inaczej. „Polonistyka” 2001, nr 8.

Bartmiński J.: Językowe podstawy obrazu świata. Lublin 2009.

Bartmiński J.: Stereotypy mieszkaja w języku. Studia etnolingwistyczne. Lublin 2007.

Firkowska-Mankiewicz A.: Czy tak samo wychowujemy dziewczęta i chłopców?. W: Co to znaczy być kobieta w Polsce. Red. A. Titkow, H. Domański. Warszawa 1995.

Jędrzejko E.: Kobieta w przystowiach, aforyzmach i anegdotach polskich. Konotacje i stereotypy. „Język a Kultura”. T. 9: Płeć w języku i kulturze. Red. J. Anusiewicz, K. Handke. Wrocław 1994.

Kajtoch W.: Ciało medialne. „Zeszyty Prasoznawcze” 2004, nr 3/4.

Karwatowska M., Szpyra-Kozłowska J.: Lingwistyka ptci. Ona i on w języku polskim. Lublin 2005.

Karwatowska M., Szpyra-Kozłowska J.: Obraz kobiety w stownictwie, frazeologii i przystowiach. W: Encyklopedia gender. Płeć w kulturze. Red. M. Rudaś-Grodzka et al. Warszawa 2014.

Karwatowska M.: „, Gazetowa” dziewczyna. Wybrane elementy wizerunku nastolatki w czasopismach młodzieżowych. W: Kultura popularna w szkole. Pobłażliwe przyzwolenie czy autentyczny dialog. Red. B. Myrdzik, M. Latoch-Zielińska. Lublin 2006.

Karwatowska M.: Autorytety w opiniach mtodzieży. Lublin 2012.

Karwatowska M.: Prawda i kłamstwo w języku młodzieży licealnej lat dziewięćdziesiatych. Lublin 2001.

Kleszczowa K.: Konstrukcje opisujące cechy osobowości. „Polonica” 1986, t. XII.

Krzaklewska E.: Wzory wchodzenia w dorostość z perspektywy genderowej. W: Kalejdoskop genderowy. W drodze do poznania ptci społeczno-kulturowej w Polsce. Red. K. Slany, B. Kowalska, M. Ślusarczyk. Kraków 2011.

Łobodzińska R.: Jaka jest kobieta w języku polskim?. „Język a Kultura”. T. 9: Pteć w języku i kulturze. Red. J. Anusiewicz, K. Handke. Wrocław 1994.

Matczak A.: Zarys psychologii rozwoju. Podręcznik dla nauczycieli. Warszawa 2003.

Niebrzydowski L.: O poznawaniu i ocenie samego siebie: na przykładzie młodzieży. Warszawa 1976.

Niesporek-Szamburska B.: Stereotyp czarownicy i jego modyfikowanie. Na przykładzie tekstów dzieci i wypowiedzi dziecięcych. Katowice 2013.

Pajdzińska A.: Kobieta najlepszym przyjacielem człowieka (przyczynek do językowego obrazu świata). W: Studia z historii języka polskiego i stylistyki historycznej. Red. C. Kosyl. Lublin 2001.

Peisert M.: „On” $i$ „ona” we wspótczesnej polszczyźnie potocznej. „Język a Kultura”. T. 9: Płeć w języku i kulturze. Red. J. Anusiewicz, K. Handke. Wrocław 1994.

Pytlos B.: Portret nastolatki kreowany na tamach miesięcznika „Dziewczyna” w latach 20052009 (rekonesans badawczy). W: Młody odbiorca w kręgu lektur pożytecznych i szkodliwych. Red. K. Heska-Kwaśniewicz przy współpr. S. Gajownik. Katowice 2012.

Uniwersalny słownik języka polskiego. T. 1. Red. S. Dubisz. Warszawa 2003.

Wacławek M.: Co ceni ,,dziewczyna”? Rozważania nad językowym obrazem świata wartości młodzieży licealnej. „Slavica XXXIX-XL. Annales Instituti Slavici Universitatis Debreceniensis”. Red. K. Agyagási, Z. Hajnády, L.K. Nagy. Debreczyn 2010-2011.

Wacławek M.: Czas na... stereotyp chłopaka i jego modyfikacje (na przyktadzie wypowiedzi młodzieży). W: A. Guzy, D. Jagodzińska, M. Wacławek, A. Zok-Smoła: Czas na... Język i dydaktyka w badaniach młodych naukowców. Katowice 2015. 
Wacławek M.: Dziewczyna we współczesnych wypowiedziach polskiej młodzieży. Przyczynek do badań językowego obrazu świata. W: Veda pre vzdelanie - vzdelanie pre vedu. Minoritné kultúry, kultúra minorit. Red. A. Janiec-Nitrai, P. Šenkár. Nitra 2010.

Wacławek M.: Kategoria wyglądu w językowo-kulturowym (auto)stereotypie dziewczyny. W: „Z Teorii i Praktyki Dydaktycznej Języka Polskiego”. T. 25. Red. D. Krzyżyk. Katowice 2016.

Wacławek M.: O profilu uczennicy w stereotypie dziewczyny. W: W krajobraz literacko-kulturowy $i$ językowy wpisane... Ksiega jubileuszowa dedykowana Profesor Bernadecie Niesporek-Szamburskiej w czterdziestolecie pracy naukowej i dydaktycznej. Red. A. Guzy, D. Krzyżyk, M. Ochwat, M. Wójcik-Dudek. Katowice 2018.

Wacław ek M.: Przemiany profilu partnerki w stereotypie dziewczyny. „Postscriptum Polonistyczne" 2017, nr 2 .

Wacławek M.: Świat wartości dziewczyny w opinii uczniów klas gimnazjalnych. W: „Z Teorii i Praktyki Dydaktycznej Języka Polskiego”. Red. H. Synowiec. T. 22. Katowice 2013.

Wacła w ek M.: Zainteresowania dziewczyny dawniej i dziś - na podstawie wypowiedzi młodzieży. W: Językowe, literackie i kulturowe ścieżki edukacji polonistycznej (tradycja i wspótczesność). Red. D. Krzyżyk, B. Niesporek-Szamburska. Katowice 2014. 